Research paper

\title{
Determinants of tourism destination competitiveness in the countries most visited by international tourists: Proposal of a synthetic index
}

\author{
José Antonio Salinas Fernández ${ }^{\mathrm{a}}$, Paula Serdeira Azevedo ${ }^{\mathrm{b}}$, José María Martín Martín,*, \\ José Antonio Rodríguez Martín ${ }^{\mathrm{d}}$ \\ ${ }^{a}$ Department of Spanish and International Economics, Faculty of Economics and Business, University of Granada, Campus de Cartuja s/n, 18071 Granada, Spain \\ ${ }^{\mathrm{b}}$ Department of Information Systems and Technology, ESGHT, Universidade do Algarve, Campus da Penha, Faro, Portugal \\ ${ }^{\mathrm{c}}$ Department of Business, Faculty of Business and Communication, International University of La Rioja, Avenida de la Paz, 137, 26004 Logroño, Spain \\ ${ }^{\mathrm{d}}$ Department of Applied Economics, Faculty of Economics and Business, University of Granada, Campus de Cartuja s/n, 18071 Granada, Spain
}

\section{A R T I C L E I N F O}

\section{Keywords:}

Tourism destination competitiveness

Synthetic index

Travel \& Tourism Competitiveness Index

Distance $\mathrm{P}_{2}$

Determinants of tourism competitiveness

\begin{abstract}
A B S T R A C T
Tourism destination competitiveness is a multidimensional concept that is widely studied in the academic literature, but multiple factors make its measurement a difficult task. In this article, we design a synthetic index to rank the 80 countries that attract the majority of international tourists by level of tourism competitiveness. In order to do this, we use all of the simple variables included in the 2017 Travel \& Tourism Competitiveness Index, proposing a new methodology for the construction of this synthetic index, which it solves the problems of aggregation of variables expressed in different measures, arbitrary weighting and duplicity of information; issues that remain unresolved by the TTCI. Likewise, we analyse the most influential dimensions in tourism competitiveness. Air transport infrastructures, cultural resources and ICT readiness are the key dimensions that explain the main disparities.
\end{abstract}

\section{Introduction}

There is agreement in the scholarly literature on the tourism sector that it is difficult to define and specify the concept of tourism competitiveness due to the influence of multiple factors or dimensions that influence a destination's success (Croes \& Kubickova 2013; Gooroochurn \& Sugiyarto 2005). Many studies have sought to identify and evaluate these factors, but no general consensus has been reached on how tourism competitiveness is defined or on how to measure it (Mazanec \& Ring 2011; Navickas \& Malakauskaite 2009). In recent decades, initiatives that discuss the need to monitor the competitiveness of tourist destinations have grown significantly, with various proposals for defining and measuring their level of competitiveness (Mazanec, Wöber, \& Zins 2007). The goal is to evaluate tourism competitiveness, since such measurement can contribute to prioritizing the actions planned and the resources allocated to benefit the sector (Barbosa, Oliveira, \& Rezende 2010). A destination's competitiveness can be measured from a quantitative perspective through analysis of data from secondary sources (hard data), or by gathering qualitative information (soft data) from surveys of tourists' opinions, tourism agents, or experts in the sector (Kozak \& Rimmington 1998, 1999).
Integrating all of this information requires building composite indicators that aggregate or synthesize a set of individual variables representing the dimensions of the phenomenon to be measured (Croes \& Kubickova 2013).

In line with the above, the main objective of this paper is to construct a synthetic indicator of tourism competitiveness using a new methodology that solves the problems of aggregation of variables expressed in different measures, the assignation of arbitrary weighting within the synthetic indicator and the duplicity of information generated by simple variables when they are added to a composite indicator. All these are unresolved issues in the Travel \& Tourism Competitiveness Index (TTCI), one of the most popular synthetic indicators worldwide developed by the WEF 2007. To achieve our goal, we have designed a synthetic indicator that includes the 90 simple variables used in the, 2017 edition of the TTCI, with a scope of 80 countries that, taken together, attract over $95 \%$ of all international tourist visits and tourism income worldwide. The methodology used to construct the synthetic indicator is based on the $\mathrm{P}_{2}$ Distance $\left(\mathrm{DP}_{2}\right)$ defined by Pena (1977), and has been applied in a multitude of academic research papers in order to construct synthetic indicators in the areas of economic and social development, welfare or quality of life among others. The main

\footnotetext{
* Corresponding author.

E-mail addresses: jasalinas@ugr.es (J.A. Salinas Fernández), pscorreia@ualg.pt (P. Serdeira Azevedo), josemaria.martin@unir.net (J.M. Martín Martín), josearm@ugr.es (J.A. Rodríguez Martín).
} 
innovation of our work is the application of $\mathrm{DP}_{2}$ method to the study of tourism destination competitiveness. The new constructed indicator will allow the 80 selected countries to be classified according to their level of competitiveness, identifying which key factors or dimensions of tourism competitiveness have the greatest influence on its measurement and which explain territorial differences best. Likewise, it will be verified whether the countries that reach highest levels of tourism competitiveness are also the same that attract the largest number of international flows of tourists. To do this, we will group the countries into large geographical areas, using just one figure to represent the average values of our synthetic indicator and the average number of international tourists attracted by each zone.

The paper is organized into four major sections following the introduction. The first of these reviews the most recent literature on tourism competitiveness, focusing on the models developed at the conceptual and empirical levels since the start of the new millennium. The second section describes the methodology to be applied in the process of constructing the synthetic index of tourism competitiveness, starting from the variables used by TTCI. The major contributions improve both the method of aggregating variables and their weighting, while also fulfilling the other conditions required of a good indicator, including identification of the most relevant dimensions in measuring tourism competitiveness. The third section presents the results of the synthetic index constructed for the 80 countries most attractive to international tourists, enabling ranking of major/minor tourism competitiveness. We also analysed the variables or partial indicators with the most influence on tourism competitiveness through study of Ivanovic's Discrimination Coefficient and the amount of relative information that each variable contributes to the synthetic index. Finally, we verify the relationship between the countries' tourism competitiveness and their capacity to attract international tourists. The fourth and last section discusses the major findings arising from our investigation and proposes measures to improve tourism competitiveness, based on its most determining factors according to the synthetic index designed.

\subsection{The concept of tourism destination competitiveness and its measurement}

Conceptualizing the competitiveness of a tourism destination involves controversy and confusion due to the scope and complexity of the concept and its multi-faceted nature, which includes different dimensions (Abreu-Novais, Ruhanen, \& Arcodia 2018). This concept has been widely studied in the scholarly literature, although a widely accepted definition has not been reached (Mazanec et al. 2007). According to Crouch and Ritchie (1999), the problem of defining competitiveness stems from the concept's character as comparative (superior relative to what?) and multidimensional (what are the salient qualities?). The complexity of defining competitiveness is compounded by the lack of consensus on the most rigorous, effective way to identify and measure the dimensions included in the competitiveness of the tourist destination (Abreu-Novais, Ruhanen, \& Arcodia 2015). According to Dwyer and Kim (2003), the main problem arises from the disparate ways in which the different dimensions have been analysed and measured, most of which are not related to each other. The scholarly literature review of the topic shows the development of general models of TDC with long lists of determining factors and attributes but lacks identification of the most important or influential factors determining tourism destination competitiveness (TDC) (Crouch 2011).

Tourism destination competitiveness is described by Ritchie and Crouch (1993) as the "ability to increase tourism expenditure, to increasingly attract visitors while providing them with satisfying, memorable experiences and to do so in a profitable way, while enhancing the well-being of destination residents and preserving the natural capital of the destination for future generations". Dupeyras and MacCallum (2013) define tourism competitiveness as "the ability of the place to optimise its attractiveness for residents and non-residents, to deliver quality, innovative, and attractive tourism services to consumers and to gain market shares on the domestic and global market places, while ensuring that the available resources supporting tourism are used efficiently and in a sustainable way". Both definitions summarize the fundamental elements included in most definitions and conceptualizations in the scholarly literature on competitiveness. First, we find competitiveness related to the notion of "ability", in reference to a destination's capability to achieve certain objectives (Abreu-Novais et al. 2015). These objectives can be categorized into three dimensions (Abreu-Novais et al. 2018): economic dimensions, dimensions associated with the well-being of the resident population (1st), attractiveness of and satisfaction provided by the destination (2nd), and sustainability (3rd). Within the first dimension, many authors hold that a tourism destination's competitiveness contributes to achieving an economic goal associated with increase in citizens' real income, rise in well-being and improvement in residents' quality of life (see Crouch \& Ritchie Crouch \& Ritchie 1999; Buhalis 2000; Bordas, 2001; Dwyer \& Kim 2003; Ritchie \& Crouch 1993; Dwyer, Mellor, Livaic, Edwards, \& Kim 2004; Bahar \& Kozak 2007). The second dimension focuses on the general attractiveness of the tourism destination and satisfaction with the experiences it offers to visitors compared to other competing destinations (Crouch \& Ritchie Crouch \& Ritchie 1999; Dwyer \& Kim 2003; Enright \& Newton 2004). The third and final dimension-related to sustainability, understood as "development that meets the needs of the present without compromising the ability of future generations to meet their own needs" (WCED 1987)—has been treated in various studies, such as Hassan (2000), Hall (2000), Ritchie and Crouch (1993), Wall and Mathieson (2006), Goffi (2013), Mihalic (2000, 2016), Evans (2016), and Cucculelli and Goffi (2016).

The most complete studies of tourism competitiveness have been developed by Crouch and Ritchie (1994, 1995, 1999, 2005), Ritchie and Crouch (1993), and Ritchie, Crouch, and Hudson (2001). These authors essentially propose a conceptual model to determine the competitiveness and success of a sustainable touristic destination, based on "the national diamond model" developed by Porter (1990). They do so by analysing a set of factors that have been identified and prioritised by CEOs of destination management organizations (DMO's). This model compares the advantages of resource allocation available at each tourist destination to the competitive advantages, defined as the resources made available by each destination to contribute to growth and development of tourism. The global environment (macro) and the competitive environment (micro) have an important effect on tourist destinations, affecting their attractiveness positively or negatively. Ritchie and Crouch (1993) identify four groups of determining factors: first, "core resources and attractors" are factors constituting the key motives for which visitors elect one destination or another. Second, "supporting factors and resources" indicate the foundation supporting development of the tourism industry (infrastructure, accessibility, services, lodging, among others). Third, "destination policy, planning and development" are relevant to guiding the directions, form and structure of tourism development and should be supported by the fourth group of factors based on "destination management", undertaken by individuals and organizations through collective action. Finally, a group of factors termed "qualifying and amplifying determinants" may be of importance in increasing or limiting tourism destination competitiveness. Subsequently, based on the model developed by Crouch \& Ritchie (1999), Dwyer developed a comprehensive model of TDC (Dwyer, Livaic, \& Mellor 2003). The works of Dwyer and Kim (2003), Dwyer et al. (2004) focus on defining a set of indicators, classified into seven large groups (Endowed Resources, Created Resources, Supporting Factors, Destination Management, Situational Conditions, Demand Factors and Market Performance Indicators) related to tourism destinations' competitiveness, and containing most of the variables and dimensions identified by Crouch and Ritchie's development model, as well as the major elements of destination competitiveness identified by Buhalis (2000), Hassan (2000) and Mihalic (2000). 
The research of Dwyer et al. (2003, 2004) focuses on industry agents from Korea and Australia in, 2001, gathering opinions on different factors determining the tourism competitiveness through workshops, while also considering another type of objective indicator. It analyses the main components of a set of 83 indicators, extracting 12 factors that explain $66.7 \%$ of the variance. The authors underscore the limitations of the analysis-the need to include the opinions of tourists on the relative importance of different indicators measuring destinations' competitiveness as well as the opinions of industry agents. They also conclude the need for a substantial volume of empirical research to develop adequate measures of destination competitiveness from the standpoint of different types of tourists and their motivation for travel. The model developed by Heath (2003) has a house-like structure composed of four essential elements: The "Foundations", or key factors of competitiveness, include culture, history, climate, business environment, security and health, transportation and communication infrastructure, location and added value of the destination, and equipment and services for the tourist, among others. The "Cement" enables connection among the different dimensions of tourism competitiveness, such as fluidity and transparency of communication channels, relationships established among stakeholders, creation of alliances and pathways for collaboration, provision of information, studies and planning, etc. The "Building Blocks", pillars fundamental to tourist development of a destination, are composed of Sustainable development policies and Global strategic and marketing management. Finally, the "Roof" represents the shared strategic vision around development of the tourism sector, an element crucial to promoting the competitiveness of the tourist destination. Other more recent contributions that focus on the theorization and development of models of TDC are those by Cvelbar, Dwyer, Koman, and Mihalič (2016), Andrades-Caldito, Sanchez-Rivero, and Pulido-Fernandez (2014), Goffi (2013), Hong (2009), Navickas and Malakauskaite (2009), and Omerzel (2006). These models focus on identifying and explaining the forces that drive competitiveness of the destination, in some cases making incremental contributions and in others significant advances in the development of complex models with exhaustive lists of indicators (Abreu-Novais et al. 2018).

In addition to models that develop a theoretical and conceptual base for TDC like those mentioned above, numerous empirical studies have been performed that apply some of the models developed, using data on specific destinations to evaluate the significance of the attributes relevant to tourism competitiveness of the destination's relative performance (Crouch 2011).Conventionally, competitiveness has been measured through composite indicators, which require collection of data based on myriad simple indicators, even though there is no direct association between these indicators and the destination's level of competitiveness (outcome) (Croes \& Kubickova 2013). OECD (2010a, b, 2011a, b, OECD, World Bank Group (2001) stress the need to approach the challenge of measuring touristic competitiveness from a multidimensional perspective but point out that there no perfect indicator system. However, establishing a list of relevant variables and encouraging improvements in measurement of them is an important step in the comprehensive analysis of competitiveness. Composite indicators thus constitute a way to avoid the problems proposed, as they enable synthesis of abundant and supposedly relevant information into a single number (Croes, 2011). Further, since they concentrate rich and relevant information, the composite indicators provide those responsible for formulating social and economic policies with a holistic image of the phenomenon to be analysed (Saltelli, 2007).

Mendola and Volo (2017) recently analysed subsequent works that focus on tourism destination competitiveness through composite indicators from a wide set of areas. Among these, we stress Gooroochurn and Sugiyarto (2005), Mazanec and Ring (2011), Blanke, Chiesa, and Crotti (2013), and Assaker, Hallak, Esposito, and O'Connor (2014), which cover a large number of countries (more than 100); and GarauTaberner (2007), Huang and Peng (2012), and Croes and Kubickova
(2013), which focus on a small number of countries (fewer than 10). Other research on the subject has been applied to various regions within a country, as in the cases of Cracolici and Nijkamp (2008), and Cracolici, Nijkamp, and Rietveld (2008), which focus on 103 Italian provinces, Croes (2011) on 16 Caribbean Islands, and Zhang, Gu, Gu, and Zhang (2011) on 16 Chinese cities. Among the most popular compound indices to measure tourism competitiveness is the TTCI, designed by the WEF (2007, 2008, 2009, 2011, 2013, 2015, 2017) and published in The Travel \& Tourism Competitiveness Report (TTCR). Since the TTCR's first publication, seven reports have been issued, each resembling a monograph on current themes related to travel and tourism. Each report includes the TTCI, which enables ranking of a wide range of countries (136 in the most recent edition), starting from the integration of a total of 90 indicators, structured into 4 sub-indices (enabling environment, T\&T policy and enabling conditions, infrastructure, and natural and cultural resources), which compose the 14 pillars of competitiveness.

The last published report (WEF, 2017) is dedicated to promoting a more inclusive and sustainable industry in the future, assuring its growth in an increasingly uncertain environment while simultaneously preserving the natural resources and local communities that depend on the industry. The TTCI integrates data from the World Economic Forum's Executive Opinion Survey and quantitative data from other sources, standardizing the variable in a range of values from 1 to 7 points, which correspond to the best and worst value, respectively. While several authors (e.g., Croes and Kubickova (2013), Crouch (2007)) have criticised different aspects of these indices, one major criticism is the methodology for aggregating variables or simple indicators, as data are not weighted within the synthetic index, and duplicated data are not removed. Following the TTCI's 2007 report, each pillar was calculated as an unweighted average of the individual variables or indicators. The four sub-indices are also calculated as an unweighted average. Finally, the global TTCI is an unweighted average of the sub-indices.

The studies analysed in the scholarly literature agree in identifying a long list of factors that determine TDC, but it is unlikely that all of these factors have the same importance or influence in determining the level of competitiveness either of the destinations in general or of the individual destinations in specific market segments (Crouch, 2011). As Cvelbar et al. (2016) write, "Further research needs to be undertaken on this issue, but given our findings, the assumption of equal weights of destination competitiveness indicators needs more critical attention than it has received thus far". For Zhang et al. (2011), in the multiple criteria decision making, the indicator's weight is crucial in measuring the importance of the indicator, and it is usually divided into two types: "One is determined by the knowledge and experience of experts or individuals, named the subjective weight; the other is based on statistical properties and measurement data, named the objective weight". We thus propose a methodology for constructing a synthetic indicator of tourism competitiveness that assigns weights objectively and resolves other problems of aggregation of variables and duplication of information. We describe this methodology in the next section.

\section{Methodology}

\subsection{The $P_{2}$ distance synthetic index}

To construct the synthetic index of tourism competitiveness, we use the $\mathrm{P}_{2}$ distance method defined by Pena (1977) from Ivanovic's distance, which modifies the weighting system of simple variables or indicators (correction factors), using the determination coefficient instead of the correlation coefficient. For a detailed study of $\mathrm{DP}_{2}$ synthetic index, see Pena (1977, 2009), Zarzosa, 1996, 2005) and Somarriba (2008). This methodology has been used widely when constructing indicators that summarize or synthesize a set of variables or partial indicators related to the object to be measured. Although this method 
was formerly used to measure social well-being in a set of territories (Zarzosa \& Somarriba, 2013), several recent studies have applied it to different fields and topics. To illustrate the vast scholarly production in recent decades, we now cite the main studies that have used Pena's $\mathrm{P}_{2}$ distance indicator (1977) to construct synthetic indicators. The mostresearched areas are thus those related to social well-being and social and economic development. On social well-being, we find studies by Pena (1977, 2009), Zarzosa (1994, 1996, 2012), Zarzosa and Somarriba (2013) and Cuenca and Rodríguez (2010). In the last decade in particular, many studies have been published in significant international journals that focus on social and economic development, such as Cuenca, Rodríguez, and Navarro (2010), Rodríguez (2012), Rodríguez and Salinas (2012), Ray (2014); Rodríguez, Holgado, and Salinas (2012); Rodríguez, Holgado, and Salinas (2013, 2014, 2015); Rodríguez, Jiménez, Salinas, and Martín (2016); and Rodríguez, Jiménez, Martín, and Salinas (2018). Other fields in which the $\mathrm{P}_{2}$ distance method has been applied are quality of life, quality of work, tourism and environment. More recently, issues related to quality of life have been analysed by Somarriba and Pena (2009), Somarriba, Zarzosa, and Pena (2015a, b) and Somarriba and Zarzosa (2016, 2018). The most important works on quality in employment are those of Ramos, Negro, Merino, and Somarriba (2010), Montero, Chasco, and Larraz (2010) and Merino, Somarriba, and Negro (2012). Research on tourism has been performed by Pérez, Blancas, González, Guerrero, Lozano, Pérez, and Caballero (2009), Lozano-Oyola, Blancas, González, and Caballero (2012), Martín, Salinas, Rodríguez, and Jiménez (2017); Martín, Rodríguez, Zermeño, and Salinas (2018); Martín, Salinas, and Rodríguez (2019), Guaita, Martín, Salinas, and Mogorrón-Guerrero (2019), and on the environment by Escobar $(2006,2008)$ and Montero, Chasco, and Larraz (2010).

Major advantages of the $\mathrm{P}_{2}$ distance synthetic index are its ability to solve problems arising from aggregating variables expressed in different measurement units, the variables' arbitrary weighting in the synthetic index and information duplicity (Somarriba \& Pena, 2009). More specifically, these advantages are its fulfilment of a series of properties to be analysed extensively in Section 2.2.

The $\mathrm{DP}_{2}$ indicator defined by Pena (1977), for any $j^{\text {th }}$ territory (in our case, countries) is the following:

$D P_{2}=\sum_{i=1}^{n} \frac{d_{i j}}{\sigma_{i}}\left(1-R_{i, i-1, \ldots ., 1}^{2}\right)$ where $i=1, \ldots, n ; j=1,2, \ldots \ldots ., m$

where:

$X_{i j}$ is the value of $i^{\text {th }}$ variable in the $j^{\text {th }}$ country.

$d_{i j}=\left|x_{i j}-x_{i *}\right|$ is the difference between the value taken by $i^{\text {th }}$ variable in the $j^{\text {th }}$ country and the minimum of the $i^{\text {th }}$ variable in the whole set of countries.

$n$ is the number of variables.

$\sigma_{i}$ is the standard deviation of $i^{\text {th }}$ variable.

$R_{i, i-1, i-2, \ldots \ldots, 1^{2}}$, is the determination coefficient in the regression of variable $x_{i}$ over.

$x_{i-1}, x_{i-2}, \ldots ., x_{1}$ already included, where $R_{1}{ }^{2}=0$.

The $\mathrm{DP}_{2}$ synthetic index evaluates differences among distinct geographic areas related to the object to be studied, in our case the tourism competitiveness of a given set of countries. As the distance, we use the minimum deviation. In other words, each country is compared to a fictitious baseline reference, the case of an imaginary country that scores the minimum value for all simple variables or indicators, yielding a value of zero on the $\mathrm{DP}_{2}$ synthetic index. The standard deviation is used to correct the scale, solving the problem of heterogeneity of unit measures; the units in which the variables were originally expressed are converted into abstract units (Somarriba \& Zarzosa, 2016).

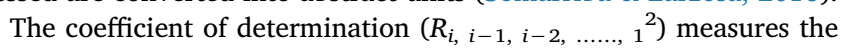
variation in each variable explained by the linear regression relative to preceding variables or partial indicators. As a result, Pena (1977) defined $\left(1-R_{i, i-1} i-2, \ldots \ldots, 1^{2}\right)$ as the "correction factor" that eliminates redundant information from the variables already in the synthetic index, such that the $\mathrm{DP}_{2}$ synthetic index only includes the new information introduced by each variable or partial indicator (Somarriba, Zarzosa, \& Pena, 2015a). The "correction factors" thus assign different levels of importance to each of the variables incorporated in the synthetic index, eliminating the problem of arbitrary weighting. Were all variables to correlate among themselves, the weighting of each would be the same in the $\mathrm{DP}_{2}$ synthetic index.

\subsection{Major properties of the $D P_{2}$ synthetic index}

As stated by Pena (1977, 2009), Zarzosa, 1996, 2005) and Somarriba (2008), the $\mathrm{DP}_{2}$ synthetic index has a set of properties that provide advantages over other aggregation methods, such as Principal Components Analysis (PCA) or Data Envelopment Analysis (DEA). These advantages include:

\section{Existence and Determination}

The mathematical function defining the $\mathrm{DP}_{2}$ synthetic index exists and should not be undetermined for the entire system of partial indicators as long as there is variance in the all components. The variance must also be a finite and non-zero value.

\section{Monotony}

When the other variables are constant, positive variance in any partial variable or indicator will have an effect of positive variance on the $\mathrm{DP}_{2}$ synthetic index. Likewise, negative variances the $\mathrm{DP}_{2}$ synthetic index will respond negatively.

III. Uniqueness

Given a set of ordered partial indicators, the mathematical function defining the $\mathrm{DP}_{2}$ synthetic index will produce a single value.

IV. Invariance

The DP2 synthetic index does not vary with changes in the origin and/or scale of the units of measure in which the partial indicators are expressed.

V. Homogeneity

As a function of partial indicators, the mathematical function defining the $\mathrm{DP}_{2}$ synthetic index is a homogeneous function of degree 1.

VI. Transitivity

If (a), (b) and (c) are three situations distinct from the object measured by the synthetic index, and $\mathrm{DP}_{2}(\mathrm{a}), \mathrm{DP}_{2}(\mathrm{~b})$ and $\mathrm{DP}_{2}(\mathrm{c})$ are the values taken by the synthetic index for these three situations, then $\mathrm{DP}_{2}(\mathrm{a})>\mathrm{Dp}_{2}(\mathrm{~b})$ and $\mathrm{DP}_{2}(\mathrm{~b})>\mathrm{DP}_{2}(\mathrm{c})$, in which case $\mathrm{DP}_{2}(\mathrm{a})>\mathrm{DP}_{2}$ (c).

VII. Exhaustiveness

The synthetic index must incorporate the most information provided by the partial indicators in a useful manner.

VIII. Additivity

In the synthetic index of distance defined to compare two territories (in our case, countries), the difference obtained between the territories measured directly by the distance indicator must equal the difference that would be obtained when comparing the synthetic indexes of each country.

IX. Invariance relative to the reference base

The synthetic index of distance defined to compare countries must be invariant relative to the reference base for each country, assuming this base is the same for all countries.

X. Conformity

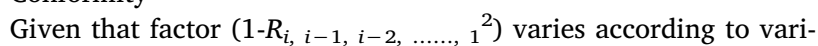
able entry order, the result of the $\mathrm{DP}_{2}$ synthetic index will also vary according to the entry order of the variables or partial indicators. It is thus necessary to establish a hierarchical ordering of variables so that the $\mathrm{DP}_{2}$ synthetic index verifies the property of uniqueness. 


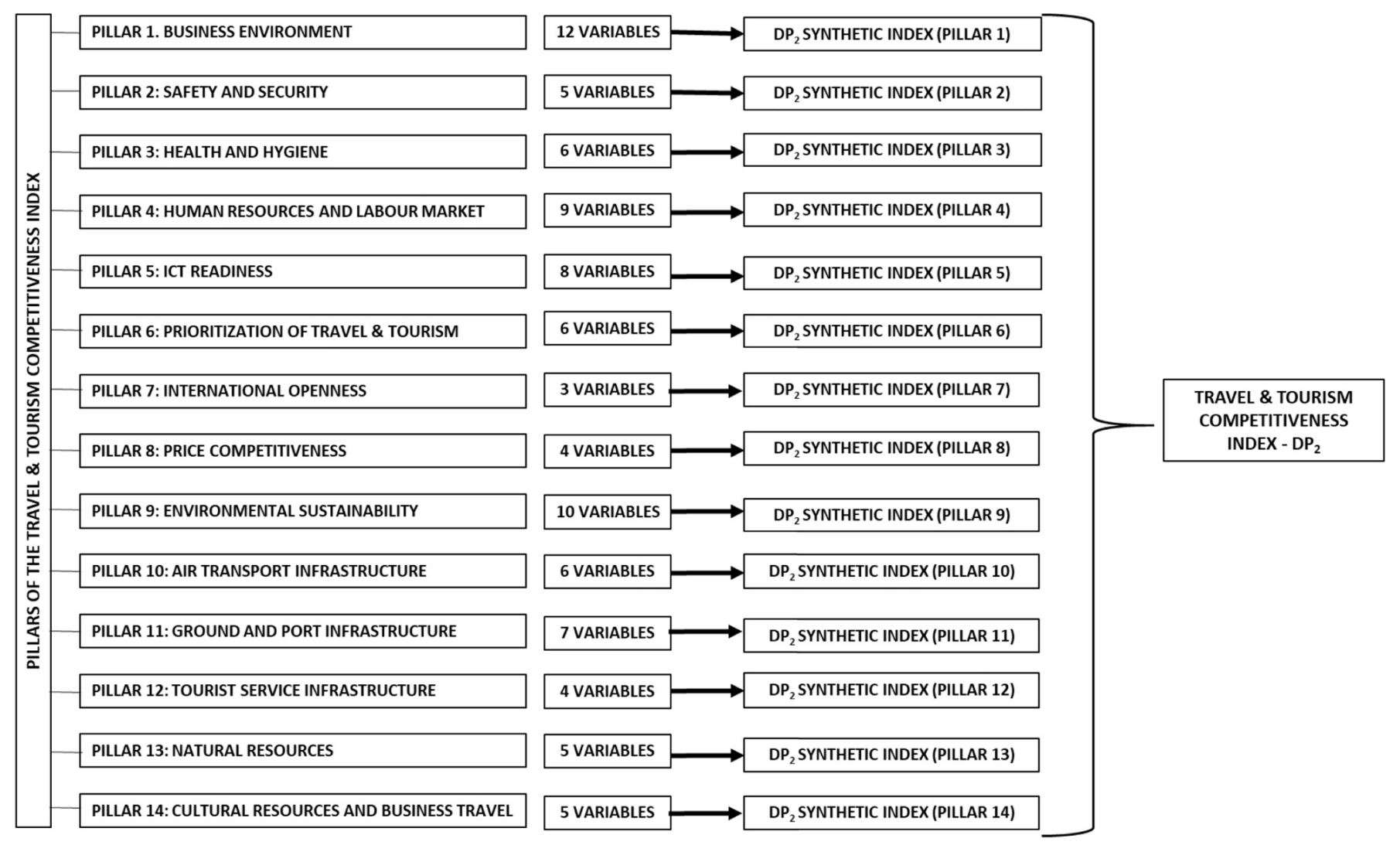

Fig. 1. Calculation procedure for Travel \& Tourism Competitiveness Index - $\mathrm{DP}_{2}$. (Source: The authors)

\section{Neutrality}

Means are non-arbitrary in importance or weighting assigned to variables in the synthetic index. The weighting is not determined in advance, as may occur in other aggregation methods, but as a result of the calculation procedure for the $\mathrm{DP}_{2}$ synthetic index.

To assure fulfilment of the properties of the $\mathrm{DP}_{2}$ synthetic index, we multiply by -1 the partial variables or indicators whose increase downgrades the goal of measuring the level of tourism competitiveness in our study (Somarriba et al., 2015a). Increase in the value of the variables thus indicates improvement in the destination's global tourism competitiveness.

2.3. Power of discrimination of the variables and volume of global information they bring to the $\mathrm{DP}_{2}$ synthetic index

To quantify the discriminant power of each variable or partial indicator included in the $\mathrm{DP}_{2}$ synthetic index, we applied the "Ivanovic's discrimination coefficient" (Ivanovic, 1974), defined as follows:

$D C_{i}=\frac{2}{m(m-1)} \sum_{j, l>j}^{k_{i}} m_{j i} m_{l i}\left|\frac{x_{j i}-x_{l i}}{\overline{X_{i}}}\right|$

where:

$m$ is the number of countries in set $\mathrm{P}$

$x_{j i}$ is the value of variable $X_{i}$ in country $j$, and $x_{l i}$ the minimum value taken by variable $X_{i}$ in country $\mathrm{j}$

$m_{j i}$ is the number of countries where the value of $X_{i}$ is $x_{j i}$

$\dot{X}_{i m}$ is the average of $X_{i}$ and

$k_{i}$ is the number of different values taken by $X_{i}$ in set $\mathrm{P}$.

As stated by Zarzosa (1994), this indicator is bounded by 0 and 2 and takes a value of zero when all values of $X_{i}$ are equal, making the discriminant power of the variable zero. The determinant coefficient takes the value of 2 when only $X_{i}$ takes a non-zero value different in a country and the remaining $m-1$ values are zero. In this case, the variable will have total discriminant power. To calculate this coefficient, the variables need not be standardized, as the coefficient does not exist when $\overline{X_{i}}=0$.

To find the global information provided by variables or partial indicators for the $\mathrm{DP}_{2}$ synthetic index, we define the "Ivanovic-Pena Global Information Coefficient" as a measure combining Ivanovic's discrimination coefficient (1974) and Pena's correction factor (1977), according to the following expression:

$C I P=\sum_{i=1}^{n} D C_{i}\left(1-R_{i, i-1, i-2, \ldots, 1}^{2}\right)$

where $n$ is the total number of variables or partial indicators, $D C_{i}$ is

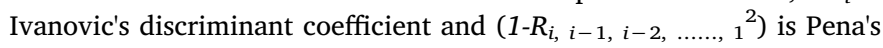
correction factor.

If we wish to measure the global impact produced by each variable on the $\mathrm{DP}_{2}$ synthetic index in relative terms, we enter each variable, ranked, using the "individual relative information coefficient" as defined by Zarzosa (1996):

$\alpha_{i}=\frac{D C_{i}\left(1-R_{i, i-1, i-2, \ldots, 1}^{2}\right)}{C I P}$

This coefficient takes values between 0 and 1 , and measures the relative amount of global information that each variable contributes to the synthetic index, considering either useful information (not duplicated) brought by each variable or partial indicator, or its discriminant power. The coefficient thus shows the relevance of each variable when measuring tourism destination competitiveness-our research objective. 


\subsection{Constructing the $\mathrm{DP}_{2}$ synthetic index of tourism competitiveness}

In calculating the proposed synthetic index of tourism competitiveness using Pena's $P_{2}$ distance method, we consider the 90 variables or individual indicators composing the TTCI designed by the World Economic Forum in its most recent published issue (2017). The dataset of all variables, which can be consulted in the bibliographic references (WEF, 2007) has been obtained from a spreadsheet available in the download section of the World Economic Forum website.

The first step to develop our synthetic indicator is constructing partial synthetic indexes for each of the 14 pillars or dimensions composing the TTCI, using the methodology previously described and integrating all the simple variables selected in each pillar.

Once the $14 \mathrm{DP}_{2}$ synthetic indexes are obtained for each dimension considered, we calculate the synthetic index of competitiveness, which will be called "Travel \& Tourism Competitiveness Index - $\mathrm{DP}_{2}$ " and will integrate the partial synthetic indexes calculated for each pillar, as shown in Fig. 1.

There are a series of limitations associated with the indicator proposed in this work, similar to those that condition the TTCI, and that were not overcome. Among them, we can highlight the most important ones, which mainly coincide with those indicated by Crouch (2011). Firstly, this index omits several factors or relevant dimensions of the tourist competitiveness of the destination, which are included in other works cited above, but could not be incorporated due to the lack of data or their insufficient quality or reliability. Secondly, the TTCI has a biannual periodicity, something that can be overcome if the data are available. This indicator does not include all countries, as it depends on the availability of data, mostly secondary. It is assumed that in order to assess certain attributes of destinations it is necessary to incorporate more primary information, which is difficult and expensive to obtain regularly. Finally, the TTCI can only be applied at a national level, the same as the proposed indicator, as there is no disaggregation of the simple variables that make it up for lower territorial levels.

\section{Results}

The Travel \& Tourism Competitiveness Index - $\mathrm{DP}_{2}\left(\mathrm{TTCI}-\mathrm{DP}_{2}\right)$ that we have constructed using the $\mathrm{P}_{2}$ distance method has 14 variables or partial indicators representing the different pillars or dimensions included in our object of study-tourism destination competitiveness-following the structure of the TTCI published by the World Economic Forum in, 2017. As described in the methodology section, the variables are integrated into the synthetic index following an entry order determined by the absolute linear correlation coefficient.

Table 1 shows the entry order of the partial indicators, by correlation coefficient, as well as the correction factors representing the new information that each partial indicator contributes when the TCCI-DP ${ }_{2}$ is incorporated. According to the results obtained, all partial indicators show high correction factors (over $30 \%$ ), which means that they contribute useful, non-duplicated information to the synthetic index. All partial indicators that compose the TTCI-DP ${ }_{2}$ are thus relevant to measuring the different dimensions of tourist destination competitiveness.

The partial indicator that enters the synthetic index first-and which has the highest correlation coefficient-is "ICT readiness". Thus, $100 \%$ of the information brought by this variable is incorporated into the TTCI-DP ${ }_{2}$. This result is not unexpected given the important role ICTs play in every country's tourism competitiveness, especially with the increasing use of mobile devices and the services provided through them. Indeed, the last issue of the "Travel \& Tourism Competitiveness Report" (WEF, 2007) states that, "as the Fourth Industrial Revolution expands, digital is increasingly becoming a basic requirement to be competitive across the T\&T industry. Countries not integrating technology and enhancing their connectivity will be left behind. In less than two years, the share of online booking has exploded, from $9 \%$ to almost
Table 1

Structure of Travel \& Tourism Competitiveness Index - $\mathrm{DP}_{2}$. Source: The authors.

\begin{tabular}{lll}
\hline Partial indicators or pillars & $\begin{array}{l}\text { Absolute correlation } \\
\text { coefficient }\end{array}$ & Correction factors \\
\hline ICT readiness & 0.8801 & 1.0000 \\
$\begin{array}{l}\text { Human resources and labour } \quad \\
\quad \text { market }\end{array}$ & 0.8243 & 0.3927 \\
Ground and port infrastructure & 0.8031 & 0.4288 \\
Tourist service infrastructure & 0.8002 & 0.5641 \\
Business environment & 0.7369 & 0.3561 \\
Air transport infrastructure & 0.7143 & 0.5021 \\
Environmental sustainability & 0.6912 & 0.4629 \\
Health and hygiene & 0.6290 & 0.4398 \\
Prioritization of travel \& tourism & 0.6155 & 0.5039 \\
Safety and security & 0.5943 & 0.5859 \\
Price competitiveness & 0.5100 & 0.5214 \\
International openness & 0.4880 & 0.6386 \\
Cultural resources and business & 0.3613 & 0.3212 \\
$\quad$ travel & 0.2087 & 0.4219 \\
Natural resources & &
\end{tabular}

$33 \% "$.

In second place, we find the partial indicator "Human resources and labour market", which involves education level of the population, business investment in training, and companies' policies and practices towards their customers, labour facilities and improvement of workers' skills, as well as extent of women's participation in the labour market. Although this dimension has a high correlation with the TTCI-DP 2 , it contains only $39.27 \%$ new information when incorporated into the synthetic index. That is, $60.73 \%$ of the information was provided by the previous variable. Countries with high rates of ICT development also tend to have a more dynamic and balanced labour market and thus more highly qualified human resources. We therefore believe that this relationship could explain the low contribution of new information by this variable.

The next partial indicators in the TTCI-DP 2 relate to the infrastructure available in the countries to provide transportation, lodging and other services oriented towards tourists. Third, fourth and sixth place are thus occupied by the variables "Ground and port infrastructure", "Tourist service infrastructure" and "Air transport infrastructure", which contribute $42.88 \%, 56.41 \%$ and $50.21 \%$ of new information not collected by previous variables, respectively. These three partial indicators contain information on aspects crucial to attracting international tourist flows, such as quantity and quality of transportation infrastructures (highways, railways, ports and airports), and availability and quality of lodging and other tourist services. In fifth place in the synthetic index, we have the variable "Business environment", which includes information on the country's legal framework and its positive or negative impact on business creation and development. This variable's contribution to the TTCI-DP 2 is relatively low, with a correction factor of $35.61 \%$, since the rest of the information it brings was included in the partial indicators previously incorporated. From the seventh position on, the variables show a lower degree of correlation with our synthetic index of touristic competitiveness. It is worth noticing, however, the greater amount of information contributed to the index by the partial indicators "International openness" (63.86\%), "Safety and security" (58.59\%), "Price competitiveness" (52.14\%) and "Prioritization of travel \& tourism" (50.39\%). The variable that contributes least is "Cultural resources and business travel" $(32.12 \%)$, second-to-last for inclusion in the TTCI-DP 2 . The last variable, "Natural resources", has the lowest absolute correlation coefficient with the synthetic index and contributes $42.19 \%$ of its information.

After analysing the structure of the synthetic index through correction factors, we examine the discriminant power of its variables or partial indicators. To do so, we use Ivanovic's Discrimination 
Table 2

Ivanovic's discrimination coefficient.

Source: The authors.

\begin{tabular}{ll}
\hline Partial variables or indicators & DC \\
\hline Cultural resources and business travel & 0.9342 \\
Air transport infrastructure & 0.6290 \\
Natural resources & 0.5041 \\
Ground and port infrastructure & 0.4952 \\
Tourist service infrastructure & 0.3967 \\
International openness & 0.3361 \\
Safety and security & 0.3295 \\
ICT readiness & 0.2995 \\
Human resources and labour market & 0.2868 \\
Prioritization of travel \& tourism & 0.2404 \\
Price competitiveness & 0.2363 \\
Business environment & 0.1807 \\
Environmental sustainability & 0.1776 \\
Health and hygiene & 0.1685 \\
\hline
\end{tabular}

Coefficient, discussed in the methodology section. This coefficient ranges from 0 to 2, reflecting the two extreme values the variable can take, zero or total discrimination power, respectively. Table 2 shows the values of Ivanovic's Discrimination Coefficient for each partial indicator of the TTCI-DP ${ }_{2}$. The variables with the greatest discriminant power are related to the natural and cultural resources in each country and to infrastructure to ensure transportation, lodging and other tourist services.

The partial indicator "Cultural resources and business travel" has the highest Ivanovic's Discrimination Coefficient (0.9342), indicating that cultural heritage resources are distributed unequally among countries, given this coefficient's relationship to the Gini Index as described in the methodology section. The same occurs with "Natural resources", which has the third-highest value of Ivanovic's DC (0.5041). The variable "Air transport infrastructure" is the second most discriminant, also showing disparities in flight availability, companies and airports among the countries analysed. In fourth place are the partial indicators "Ground and port infrastructure" and "Tourist service infrastructure", elements important to tourist services available, such as resources and quality of infrastructure available in the countries for transportation, lodging and other tourist-oriented services. In a middle position in terms of discriminant power are the partial indicators "International openness", "Safety and security", "ICT readiness" and "Human resources and labour market". "International openness" includes information on obstacles or barriers that countries pose to the entrance of international tourists, as well as to trading of goods and services. The other three factors create a favourable or unfavourable environment for the tourist, such as criminal activities, level of protection guaranteed by authorities, degree of ICT development and labour environment.

Less discriminant partial indicators are related to government policies to promote travel and tourism, indicating that these pillars of competitiveness are less unequal among the countries analysed. From major to minor discriminant power we find "Prioritization of travel \& tourism", "Price competitiveness", "Business environment", "Environmental sustainability" and "Health and hygiene", which contribute important information, such as priority governments grant tourism in their investment policies, development and marketing, price of tourist services, legal framework and ease of creating companies, environmental regulation and protection, and finally provision of sanitary resources, hygiene and contagious disease control. So far, we have been studying the useful information that each partial indicator contributes to the TTCI-DP ${ }_{2}$ synthetic index through the correction factor and its discriminant power separately. If we combine these two types of information, we obtain the individual relative information coefficient $(\alpha)$, which measures the contribution in relative terms made by each variable or partial indicator to the tourism competitiveness $\mathrm{DP}_{2}$
Table 3

Contribution of individual relative information coefficient to TTCI$\mathrm{DP}_{2}$.

Source: The authors.

\begin{tabular}{ll}
\hline Partial indicators & $\alpha$ \\
\hline Air transport infrastructure & 0.1239 \\
Cultural resources and business travel & 0.1177 \\
ICT readiness & 0.1175 \\
Tourist service infrastructure & 0.0878 \\
International openness & 0.0842 \\
Natural resources & 0.0834 \\
Ground and port infrastructure & 0.0833 \\
Safety and security & 0.0757 \\
Price competitiveness & 0.0483 \\
Prioritization of travel \& tourism & 0.0475 \\
Human resources and labour market & 0.0442 \\
Environmental sustainability & 0.0323 \\
Health and hygiene & 0.0291 \\
Business environment & 0.0252 \\
\hline
\end{tabular}

synthetic index we have constructed. The sum of the individual contributions of each partial indicator is 1 .

The partial indicators with high correction factors and great discriminant power will thus individually contribute large amounts of information to TTCI-DP ${ }_{2}$ synthetic index. This high contribution means that the factors are determining factors in measuring countries' tourism competitiveness. We have thus fulfilled our goal of identifying these determinants. As Table 3 shows, the first seven partial indicators together contribute $70 \%$ of the information to the TTCI-DP ${ }_{2}$ synthetic index, and the following seven the remaining $30 \%$. The factors determining tourism competitiveness in the 80 countries most visited by international tourists are thus those related to infrastructure of transportation and lodging available, cultural and natural resources, level of ICT development and country's degree of openness.

The most relevant pillars for measuring tourism destination competitiveness are "Air transport infrastructure", "Cultural resources and business travel" and "ICT readiness", which taken together explain almost $36 \%$ of existing disparities among the countries analysed. "Tourist service infrastructure", "International openness", "Natural resources" and "Ground and port infrastructure" contribute 8-9\% information individually. The pillars less relevant to explaining tourism competitiveness, in contrast, involve favourable or unfavourable influence of the environment ("Business environment", "Health and hygiene", "Human resources and labour market" and "Safety and security"), and policies and conditions for development of the travel and tourism sector ("Environmental sustainability", "Prioritization of travel \& tourism" and "Price competitiveness").

Now that we have identified the pillars with the strongest influence in determining the tourism competitiveness of the 80 countries that receive the most international tourists, we will analyse the classification of those countries resulting from the synthetic index of tourism competitiveness (TTCI-DP ${ }_{2}$ ) and the aggregate data by large geographical regions. Table 5 (Appendix) shows the countries, ranked from major to minor distance from an imaginary country in which all partial indicators associated with different pillars or dimensions of tourism competitiveness take the minimum value and would thus have a $\mathrm{DP}_{2}$ synthetic index of zero. In, 2017, the country with the greatest tourism competitiveness was the United States, with a distance of 26.79 points from the imaginary baseline country. Zimbabwe was the least competitive, at a distance of 8.91 points. The TTCI-DP ${ }_{2}$ thus ranges 17.87 points between the highest and lowest country. The five countries in the best position in the synthetic index are the United States, Singapore, Japan, Germany and Spain, which receive almost $20 \%$ of international tourists attracted by the set of 80 countries considered in our analysis. Widening the selection, we verify that the 25 countries in the best position in the synthetic index attract $49.24 \%$ of total volume of 
Table 4

Measures of TTCI-DP 2 by large geographic areas. Source: The authors.

\begin{tabular}{llllll}
\hline Areas & $\begin{array}{l}\text { No. of } \\
\text { countries }\end{array}$ & Range & Mean & $\begin{array}{l}\text { Standard } \\
\text { deviation }\end{array}$ & $\begin{array}{l}\text { Coefficient of } \\
\text { variation }\end{array}$ \\
\hline Africa & 6 & 8.71 & 13.92 & 3.74 & 0.269 \\
Balkans and & 7 & 5.52 & 18.78 & 1.86 & 0.099 \\
$\quad$ Eastern & & & & & \\
$\quad$ Europe & & 7.15 & 23.48 & 2.51 & 0.107 \\
East Asia and the & 7 & & & & \\
$\quad$ Pacific & & 11.47 & 15.82 & 2.99 & 0.189 \\
Eurasia & 6 & 10.35 & 20.63 & 3.57 & 0.193 \\
Middle East & 7 & & & & 0.182 \\
North and central & 7 & 4.68 & 23.08 & 1.94 & 0.084 \\
$\quad$ America & & 4.20 & 17.13 & 1.55 & 0.091 \\
Northern Europe & 7 & 13.20 & 17.28 & 4.24 & 0.246 \\
South America & 6 & 7.40 & 21.36 & 2.33 & 0.109 \\
Southeast Asia & 10 & 4.20 & 23.97 & 1.35 & 0.056 \\
$\quad$ Southern Europe & 8 & 17.87 & 19.65 & 4.15 & 0.211 \\
Western Europe & 9 & & & & \\
TOTAL & 80 & & & & \\
\hline
\end{tabular}

international tourists, while the 25 countries in worse position receive only $15.28 \%$. These data show very unequal distribution of ability to attract international tourists, as well as a significant concentration of travellers in a small number of countries.

Grouping the countries by large geographic areas (Table 4) provides a clearer view of the differences in tourism destination competitiveness. According to our synthetic index TTCI-DP ${ }_{2}$, the most competitive region is western Europe (with an average value of 23.97 points), with Germany, Austria, Switzerland, United Kingdom, France and Holland distinguished for both attractiveness and very similar values. Next are East Asia and the Pacific, with an average value of 23.48 points and Japan, Hong Kong SAR, Australia and New Zealand as leaders.

Northern Europe is the third-most competitive areas, with a value very close to that of the synthetic index (23.08 points) of the preceding areas, led by Norway, Finland, Sweden and Denmark. The next area is southern Europe, with Spain and Portugal in the best positions, although the value of the TTCI-DP 2 (21.36 points) is almost 2 points less than that of the three previous areas. Countries in Africa and Eurasia occupy the last positions in the synthetic index of tourism competitiveness (TTCI-DP ${ }_{2}$ ), with average values of 13.92 and 15.82 points, respectively. In Africa, Morocco, South Africa, Tunisia and Egypt lead the classification. Of the countries between Europe and Asia (Eurasia), the best-positioned countries are Azerbaijan, Georgia and Russia.

Fig. 2 compares levels of tourism competitiveness of the 80 countries chosen, grouped by large geographical area according to the synthetic index (TTCI-DP 2 ), as well as the average number of international travellers attracted by each area. To visualize the different regions' positions more clearly, a line of discontinuous points was drawn along each axis to show the average of each variable represented, forming four quadrants.

We observe that the areas located in the upper right quadrant are optimal because they achieve high levels of tourism competitiveness and also attract greater flows of international tourists. This quadrant contains the regions of Western and Southern Europe, East Asia and the Pacific, and North and Central America. In contrast, the lower left quadrant represents the worst scenario. The regions located here are the least competitive and attract a lower volume of international tourists. This quadrant contains Africa, Eurasia and South America. Finally, the remaining quadrants represent unusual positions, as it is not common to find areas with high levels of tourism competitiveness and low market share in attracting international tourists, as occurs in higher left quadrant and the inverse (lower right quadrant). Fig. 2 shows that Northern Europe has high values in the synthetic index of tourism competitiveness but nevertheless does not attract a large volume of international tourism. It is also worth noting that no area in the lower right quadrant shows a combination of low levels of tourism competitiveness with high volumes of tourists.

\section{Discussion and conclusions}

Applying the $\mathrm{P}_{2}$ distance methodology indicated to measure TDC by constructing a synthetic indicator has enabled us to identify the factors or dimensions that most strongly determine the differences in competitiveness among the destinations analysed. The properties that the $\mathrm{DP}_{2}$ synthetic indicator fulfil and the iterative process followed to reach the final solution make it an ideal indicator to classify destinations according to their level of tourism competitiveness. Among other advantages, the indicator eliminates redundant information in the variables by integrating it into a composite indicator and assigns weights objectively, following the property of neutrality explained above.

This study's findings focus primarily on identifying the most influential dimensions of tourism competitiveness, enabling design of the most effective and important policies and actions to achieve the goal of improving the international competitiveness of a destination. The results can also be contrasted with the main theoretical and conceptual models of TDC, as well as with other empirical studies performed. Further, we have analysed the countries with the greatest tourism competitiveness, grouped them into large regions of the world according to the classification produced by the synthetic indicator developed.

According to the results obtained, the most significant factors determining tourism competitiveness of the 80 destinations analysed can be grouped into two categories. First, those termed "Core Resources and Attractors" in the model developed by Crouch \& Ritchie (1999) are the key motivators for visiting a destination. Second, the "Supporting Factors and Resources" provide the foundation for establishing a solid, successful tourist industry. Of the 14 pillars included in our synthetic indicator TTCI-DP 2 , the first 7 fall within these two groups of factors, together explaining $70 \%$ of the synthetic indicator's variance (Table 3 ). The 7 remaining pillars contribute less to explaining the differences in competitiveness among the countries and are associated with the other groups of factors identified by Crouch and Ritchie.

If we compare the results to the model developed by Dwyer and Kim (2003), we again confirm the importance, on the one hand, of the "Core resources", which include "Endowed resources" (Natural resources, heritage and culture) and "Created resources" (Tourism infrastructure, special events, activities and entertainment, etc.). We also confirm the importance of "Supporting factors and resources"-that is, the general infrastructures, quality of services for the tourist and accessibility of the destination, among other factors. As Table 3 shows, the pillars of "Cultural resources and business travel", "Tourist service infrastructure" and "Natural resources" belong to "Core resources", whereas "Air transport infrastructure", "ICT readiness", "International openness" and "Ground and port infrastructure" are termed "Supporting factors and resources".

As to the model developed by Heath (2003), the most influential dimensions determining tourism competitiveness in the 80 countries analysed in our study belong to those termed the "Foundations". As Table 3 shows, the pillars "Air transport infrastructure", "ICT readiness", and "Ground and port infrastructure" are considered as the "Enablers", since they provide a solid base on which to build a successful tourism industry. The pillars "Cultural resources and business travel" and "Natural resources" would then be the "Key attractors", as they constitute the primary motivations for inbound tourism. The pillar "Tourist service infrastructure", which also makes a high relative individual contribution to the synthetic indicator TTCI-DP 2 , is included in the factors termed "Facilitators", factors that influence the experience and perceived value of the trip.

Among the empirical studies that have constructed composite indicators and analysed the weights of the factors or dimensions that determine TDC, we highlight Gooroochurn and Sugiyarto (2005). Our 


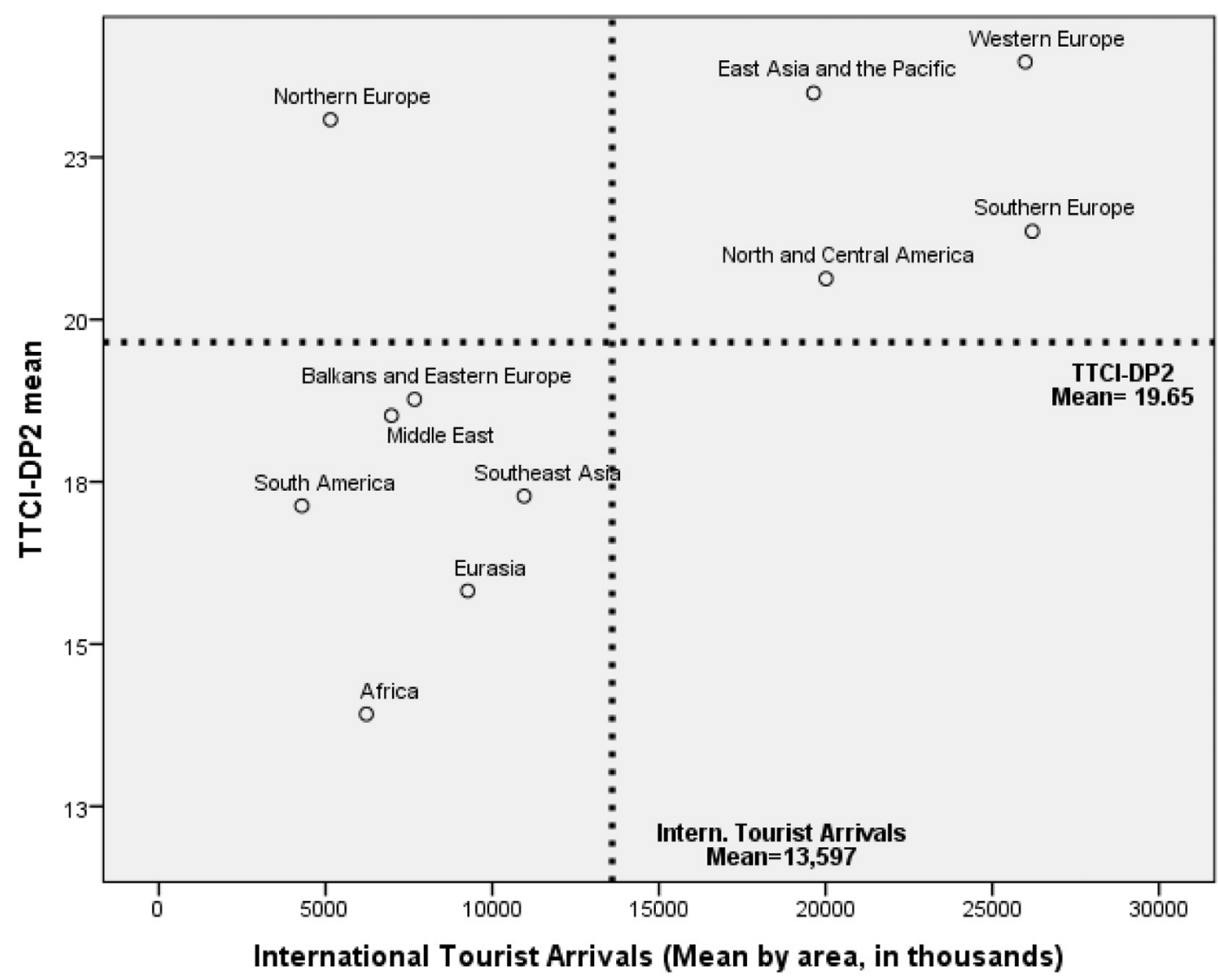

Fig. 2. Comparison between the synthetic index (TTCI-DP $\mathrm{P}_{2}$ ) and the number of international travellers attracted by large geographical areas. (Source: The authors)

results, like theirs, show that technology is one of the factors that most strongly differentiates international tourist destinations; dimensions associated with the natural environment register lower weights.

Subsequently, Crouch (2011) conducted an investigation with a panel of experts among which were "destination managers and tourism researchers", to identify the factors or attributes that affect the competitiveness of tourist destinations, based on the model developed by Crouch and Ritchie (1999). A total of 36 sub-factors were analysed, grouped into five major groups of factors, 10 of which were found to be statistically significantly greater than average measures of determination. Clearly, of the five main groups of factors, "Core Resources and Attractors" is the group that determines the competitiveness of tourist destinations, since 6 of the 10 identified sub-factors are included in it. Next, there is the group called "Supporting Factors and Resources", with 2 sub-factors (Infrastructure and Accessibility). As can be seen, the results of our work coincide with those of Crouch (2011), since the 7 pillars or dimensions that contribute most to explaining the competitiveness of the 80 tourist destinations, belong to these two groups of factors (Table 3).

According to the TTCI-DP ${ }_{2}$ values, the country positioned first is the United States, followed by Singapore, Japan, Germany and Spain. These five countries receive almost $20 \%$ of all international tourists attracted by the set of countries analysed, while the 25 countries in worst position in our synthetic index attract only $15.28 \%$, with Zimbabwe in last position.

If we examine large geographical area, Western and Southern Europe, East Asia and the Pacific, North and Central America achieve the highest levels of tourism competitiveness. The case of Northern Europe countries is paradigmatic, however, in that they attain high levels of competitiveness but cannot attract large volumes of international tourists.
The comparison made between the level of competitiveness reached by the 80 countries analysed, according to the TTCI-DP2 synthetic indicator, and the number of international visitors arriving, does not imply the assumption that greater competitiveness of a destination equals a greater number of visitors. In our research, we only found that the arrivals of international tourists are concentrated, to a great extent, in the destinations that reach higher levels of competitiveness, although not always, as is the case of Northern European countries. As highlighted by the relevant literature on the subject, the competitiveness of a destination must be evaluated in relation to its capacity to meet the objectives set in a tourism destination strategy, which are not necessarily related to the maximization of visitor arrivals.

Certainly, neither improvements in competitiveness nor the success obtained by a tourist destination should be associated solely with improvement in the attraction of visitors. Policies focused exclusively on the growth of demand can lead to a saturation of destinations and the consequent rejection of premises (Martín, Rodríguez, et al., 2018). Therefore, numerous European cities are suffering the consequences of decades of pro-growth policies (Dredge, Gyimóthy, Birkbak, Jensen, \& Madsen, 2016). From an environmental point of view, one of the factors that has most impact on the sustainability of the destination is overcoming the load capacity (Qiu, Fan, Lyu, Lin, \& Jenkins, 2018). For this reason, the growth policies for arrivals must assume other dimensions associated with the environmental, social and economic sustainability of the destination.

The concept of sustainability refers to the capacity of productive activities to meet present needs without compromising the possibilities of future generations (United Nations, 1987). The World Tourism Organization points out that sustainable tourism models must meet the needs of current tourists and of the receiving regions, while protecting the resources on which these activities are based, guaranteeing 
opportunities for the future (WTO, 1993). Growth in the number of arrivals should be a reflection of the competitiveness of the destination and its good work, and not an absolute objective that does not consider the circumstances of the destination.

As our analysis verifies, a large portion of the disparities in tourism competitiveness among the countries is based on the key pillars or dimensions we have noted. If we wish to improve tourism competitiveness, we must thus focus on policies to promote and boost the tourism sector by developing it in directions that facilitate international tourist visits.

First, improving infrastructures and air services is fundamental to achieving this goal. Countries must expand the flights and companies operating in each country, as well as the rest of their transport infrastructure, to facilitate access to foreign travellers.

Second, countries must increase the value of their cultural and natural resources by investing in the rehabilitation and maintenance of historic and artistic heritage, as well as environmental protection.

Third, developing ICTs is a key issue, especially those oriented to commerce and tourist services and delivered through mobile devices. As Martín, Rodríguez, Zermeño, and Salinas (2018) indicate, "actions must be proposed that promote the competitiveness of the destination, as is the case of the use of new technologies that provide valuable data on consumers in the tourism industry to conduct tourism intelligence".

Last, but not least, it is important to improve and expand on infrastructures for lodging and services to tourists, as well as to allow more flexibility in entry visas for international travellers in countries with less open to foreigners.

In the future, the methodology proposed in this paper could constitute a very interesting line of research to be explored, with the aim of constructing synthetic indicators that integrate variables representative of the key dimensions of tourism competitiveness previously studied in the scientific literature.

When applying this methodology to new territorial areas, infinite possibilities open up. Country-wise, our research can be applied to any area of the world, either grouping those with similar social, economic or cultural characteristics or comparing countries of very different areas from a tourism development or economic point of view. At a higher level of disaggregation, the applications are also very broad, either as regions, countries or municipalities of the same or different countries. Similarly, the temporal analysis will allow for the monitoring and evaluation of the progresses made in tourism competitiveness of the analysed territories. For all this, we believe that this methodology contributes significantly to improving the measurement of a multidimensional concept such as tourism competitiveness.

\section{Declaration of Competing Interest}

All authors declare no conflicts of interest to declare.

\section{Acknowledgment}

This research has been partially supported by Spanish Ministry of Economy, Industry and Competitiveness, the State Research Agency (SRA) and European Regional Development Fund (ERDF) (project reference ECO2017-86822-R).

\section{Appendix A. Appendix}

Table 5

Classification of countries in travel \& tourism competitiveness index - $\mathrm{DP}_{2}$ Source: The authors.

\begin{tabular}{|c|c|c|c|c|}
\hline Position & Country & AREA & TTCI-DP $_{2}$ & International tourist visits (Thousands) \\
\hline 1 & United States & North and Central America & 26.78 & $77,510.28$ \\
\hline 2 & Singapore & Southeast Asia & 25.92 & $12,051.93$ \\
\hline 3 & Japan & East Asia and the Pacific & 25.90 & $19,737.41$ \\
\hline 4 & Germany & Western Europe & 25.59 & $34,971.46$ \\
\hline 5 & Spain & Southern Europe & 25.14 & $68,521.26$ \\
\hline 6 & Hong Kong SAR & East Asia and the Pacific & 25.11 & $26,686.03$ \\
\hline 7 & Norway & Northern Europe & 25.11 & 5361.00 \\
\hline 8 & Australia & East Asia and the Pacific & 25.06 & 7444.40 \\
\hline 9 & Austria & Western Europe & 24.98 & $26,718.95$ \\
\hline 10 & Switzerland & Western Europe & 24.85 & 9304.63 \\
\hline 11 & New Zealand & East Asia and the Pacific & 24.81 & 3039.00 \\
\hline 12 & Finland & Northern Europe & 24.80 & 2622.04 \\
\hline 13 & United Kingdom & Western Europe & 24.55 & $34,435.84$ \\
\hline 14 & France & Western Europe & 24.55 & $84,451.62$ \\
\hline 15 & Sweden & Northern Europe & 24.24 & $10,522.00$ \\
\hline 16 & Netherlands & Western Europe & 24.14 & $15,007.00$ \\
\hline 17 & United Arab Emirates & Middle East & 23.93 & $14,200.00$ \\
\hline 18 & Canada & North and Central America & 23.91 & $17,977.29$ \\
\hline 19 & Portugal & Southern Europe & 23.90 & $10,140.20$ \\
\hline 20 & Denmark & Northern Europe & 23.48 & $10,424.00$ \\
\hline 21 & Ireland & Western Europe & 23.26 & 9528.00 \\
\hline 22 & Estonia & Northern Europe & 23.07 & 2988.73 \\
\hline 23 & Taiwan, China & East Asia and the Pacific & 22.64 & $10,439.79$ \\
\hline 24 & Belgium & Western Europe & 22.45 & 8354.75 \\
\hline 25 & Korea, Rep. & East Asia and the Pacific & 22.12 & $13,231.65$ \\
\hline 26 & Malaysia & Southeast Asia & 21.94 & $25,721.25$ \\
\hline 27 & Qatar & Middle East & 21.54 & 2929.63 \\
\hline 28 & Malta & Southern Europe & 21.50 & 1783.37 \\
\hline 29 & Greece & Southern Europe & 21.46 & $23,599.46$ \\
\hline 30 & Czech Republic & Western Europe & 21.39 & $11,148.00$ \\
\hline 31 & Panama & North and Central America & 21.34 & 2109.37 \\
\hline 32 & Slovenia & Balkans and Eastern Europe & 21.17 & 2706.78 \\
\hline 33 & Italy & Southern Europe & 20.87 & $50,731.77$ \\
\hline 34 & Croatia & Southern Europe & 20.80 & $12,683.18$ \\
\hline 35 & Costa Rica & North and Central America & 20.69 & 2660.26 \\
\hline
\end{tabular}


Table 5 (continued)

\begin{tabular}{|c|c|c|c|c|}
\hline Position & Country & AREA & TTCI-DP $_{2}$ & International tourist visits (Thousands) \\
\hline 36 & Lithuania & Northern Europe & 20.45 & 2071.30 \\
\hline 37 & Latvia & Northern Europe & 20.43 & 2023.50 \\
\hline 38 & Poland & Balkans and Eastern Europe & 19.91 & $16,728.00$ \\
\hline 39 & Chile & South America & 19.85 & 4478.34 \\
\hline 40 & Thailand & Southeast Asia & 19.72 & $29,923.19$ \\
\hline 41 & Hungary & Balkans and Eastern Europe & 19.49 & $14,316.00$ \\
\hline 42 & Cyprus & Southern Europe & 19.48 & 2659.40 \\
\hline 43 & Slovak Republic & Balkans and Eastern Europe & 19.37 & 6816.00 \\
\hline 44 & Azerbaijan & Eurasia & 18.96 & 1921.93 \\
\hline 45 & Bulgaria & Balkans and Eastern Europe & 18.85 & 7099.00 \\
\hline 46 & China & East Asia and the Pacific & 18.75 & $56,885.70$ \\
\hline 47 & Georgia & Eurasia & 18.26 & 2281.97 \\
\hline 48 & Israel & Middle East & 18.03 & 2799.50 \\
\hline 49 & Uruguay & South America & 18.02 & 2773.11 \\
\hline 50 & Jordan & Middle East & 17.97 & 3761.07 \\
\hline 51 & Oman & Middle East & 17.90 & 1897.00 \\
\hline 52 & Sri Lanka & South-East Asia & 17.87 & 1798.38 \\
\hline 53 & Saudi Arabia & Middle East & 17.82 & $17,994.22$ \\
\hline 54 & Mexico & North and Central America & 17.78 & $32,093.32$ \\
\hline 55 & Turkey & Southern Europe & 17.74 & $39,478.00$ \\
\hline 56 & Morocco & North Africa & 17.62 & $10,176.76$ \\
\hline 57 & South Africa & Southern Africa & 17.52 & 8903.77 \\
\hline 58 & Indonesia & Southeast Asia & 17.48 & $10,406.76$ \\
\hline 59 & Jamaica & North and Central America & 17.45 & 2123.04 \\
\hline 60 & Romania & Balkans and Eastern Europe & 16.99 & 2234.52 \\
\hline 61 & Brazil & South America & 16.74 & 6305.84 \\
\hline 62 & Russian Federation & Eurasia & 16.51 & $31,346.49$ \\
\hline 63 & Dominican Republic & North and Central America & 16.43 & 5599.86 \\
\hline 64 & Argentina & South America & 16.31 & 5736.38 \\
\hline 65 & Kazakhstan & Eurasia & 16.27 & 4559.50 \\
\hline 66 & Peru & South America & 16.20 & 3455.71 \\
\hline 67 & Colombia & South America & 15.65 & 2978.18 \\
\hline 68 & Albania & Balkans and Eastern Europe & 15.65 & 3784.36 \\
\hline 69 & Tunisia & North Africa & 15.27 & 5359.31 \\
\hline 70 & Philippines & Southeast Asia & 15.23 & 5360.68 \\
\hline 71 & Vietnam & Southeast Asia & 14.76 & 7943.60 \\
\hline 72 & Egypt & North Africa & 14.33 & 9139.10 \\
\hline 73 & Ukraine & Eurasia & 14.12 & $12,428.29$ \\
\hline 74 & India & Southeast Asia & 13.98 & 8027.13 \\
\hline 75 & Lao PDR & Southeast Asia & 13.15 & 3543.33 \\
\hline 76 & Cambodia & Southeast Asia & 12.72 & 4775.23 \\
\hline 77 & Iran, Islamic Rep. & Middle East & 12.46 & 5237.00 \\
\hline 78 & Kyrgyz Republic & Eurasia & 10.78 & 3051.00 \\
\hline 79 & Algeria & North Africa & 9.88 & 1710.00 \\
\hline 80 & Zimbabwe & Southern Africa & 8.91 & 2056.59 \\
\hline
\end{tabular}

\section{References}

Abreu-Novais, M., Ruhanen, L., \& Arcodia, C. (2015). Destination competitiveness: What we know, what we know but shouldn't and what we don't know but should. Current Issues in Tourism, 19(6), 1-21.

Abreu-Novais, M., Ruhanen, L., \& Arcodia, C. (2018). Destination competitiveness: A phenomenographic study. Tourism Management, 64, 324-334.

Andrades-Caldito, L., Sanchez-Rivero, M., \& Pulido-Fernandez, J. I. (2014). Tourism destination competitiveness from a demand point of view: An empirical analysis for Andalusia. Tourism Analysis, 19(4), 425-440.

Assaker, G., Hallak, R., Esposito, V., \& O'Connor, P. (2014). An empirical operationalization of countries' destination competitiveness using partial least squares modelling. Journal of Travel Research, 53(1), 26-43.

Bahar, O., \& Kozak, M. (2007). Advancing destination competitiveness research: Comparison between tourists and service providers. Journal of Travel \& Tourism Marketing, 22(2), 61-71.

Barbosa, L. G. M., Oliveira, C. T. F. D., \& Rezende, C. (2010). Competitiveness of tourist destinations: The study of 65 key destinations for the development of regional tourism. Revista de Administração Pública, 44(5), 1067-1095.

Blanke, J., Chiesa, T., \& Crotti, R. (2013). The travel \& tourism competitiveness index 2013: Contributing to national growth and employment. In J. Blanke, \& T. Chiesa (Eds.). The travel \& tourism competitiveness report 2013: Reducing barriers to economic growth and job creation (pp. 3-41). Geneva: World Economic Forum.

Bordas, E. (2001). Improving public-private sectors cooperation in tourism: A new paradigm for destinations. Tourism Review, 56(3/4), 38-41.

Buhalis, D. (2000). Marketing the competitive destination in the future. Tourism Management, 21(1), 97-116.

Cracolici, M. F., \& Nijkamp, P. (2008). The attractiveness and competitiveness of tourist destinations: A study of Southern Italian regions. Tourism Management, 30, 336-344. Cracolici, M. F., Nijkamp, P., \& Rietveld, P. (2008). Assessment of tourism competitiveness by analysing destination efficiency. Tourism Economics, 14(2), 325-342.

Croes, R. (2011). Measuring and explaining competitiveness in the context of small island destinations. Journal of Travel Research, 50(4), 431-442.

Croes, R., \& Kubickova, M. (2013). From potential to ability to compete: Towards a performance based tourism competitiveness index. Journal of Destination Marketing and Management, 2(3), 146-154.

Crouch, G. I. (2007). Measuring tourism competitiveness: Research, theory and the WEF index. Dudedin, New Zealand: Paper presented at Anzmac3-5 (December).

Crouch, G. I. (2011). Destination competitiveness: An analysis of determinant attributes. Journal of Travel Research, 50(1), 27-45.

Crouch, G. I., \& Ritchie, J. R. B. (1994). Destination competitive-Exploring foundations for a long-term research programme. Proceedings of the administrative sciences association of canada 1994 annual conference (pp. 79-88). Nova Scotia: Halifax.

Crouch, G. I., \& Ritchie, J. R. B. (1995). Destination competitiveness and the role of the tourism enterprise. Proceedings of the fourth annual business congress. vol. 43-48. Proceedings of the fourth annual business congress (pp. 13-16). Istanbul, Turkey, July.

Crouch, G. I., \& Ritchie, J. R. B. (1999). Tourism, competitiveness, and societal prosperity. Journal of Business Research, 44, 137-152.

Cucculelli, M., \& Goffi, G. (2016). Does sustainability enhance tourism destination competitiveness? Evidence from Italian destinations of excellence. Journal of Cleaner Production, 111(Part B), 370-382.

Cuenca, E., \& Rodríguez, J. A. (2010). Medición de las disparidades entre indicadores asociados al bienestar social en los Países Menos Adelantados (PMA) de Asia. Revista de Economía Mundial, 25, 83-108.

Cuenca, E., Rodríguez, J. A., \& Navarro, M. (2010). The features of development in the Pacific countries of the African, Caribbean and Pacific group. Social Indicators Research, 99, 469-485. 
Cvelbar, L. K., Dwyer, L., Koman, M., \& Mihalič, T. (2016). Drivers of destination competitiveness in tourism: A global investigation. Journal of Travel Research, 55(8), 1041-1050.

Dredge, D., Gyimóthy, S., Birkbak, A., Jensen, T. E., \& Madsen, A. K. (2016). The impact of regulatory approaches targeting collaborative economy in the tourism accommodation sector: Barcelona, Berlin, Amsterdam and Paris. Impulse Paper N. 9 prepared for the European Commission DG growthCopenhagen: Aalborg University (2016).

Dupeyras, A., \& MacCallum, N. (2013). Indicators for measuring competitiveness in tourism: A guidance document. OECD Tourism PapersParis: OECD Publishing. https:// doi.org/10.1787/5k47t9q2t923-en 2013/02.

Dwyer, L., \& Kim, C. (2003). Destination competitiveness: Determinants and indicators. Current Issues in Tourism, 6(5), 369-414.

Dwyer, L., Livaic, Z., \& Mellor, R. (2003). Competitiveness of Australia as a tourist destination. Journal of Hospitality and Tourism Management, 10(1), 60-78.

Dwyer, L., Mellor, R., Livaic, Z., Edwards, D., \& Kim, C. (2004). Attributes of destination competitiveness: A factor analysis. Tourism Analysis, 9(1), 91-101.

Enright, M. J., \& Newton, J. (2004). Tourism destination competitiveness: A quantitative approach. Tourism Management, 25(6), 777-788.

Escobar, L. (2006). Indicadores sintéticos de calidad ambiental: Un modelo general para grandes zonas urbanas. Eure, 32(96), 73-98.

Escobar, L. (2008). Indicadores ambientales sintéticos: Una aproximación conceptual desde la estadística multivariante. Gestión y Medioambiente, 11(1), 121-140.

Evans, N. G. (2016). Sustainable competitive advantage in tourism organizations: A strategic model applying service dominant logic and tourism's defining characteristics. Tourism Management Perspectives, 18, 14-25.

Garau-Taberner, J. (2007). Measuring destination competitiveness: An exploratory study of the canaries, mainland Spain, France, the Balearics and Italy. Tourism Today, 7 , 61-77.

Goffi, G. (2013). A model of tourism destinations competitiveness: The case of the Italian destinations of excellence. Anuario Turismo y Sociedad, 14, 121-147.

Gooroochurn, N., \& Sugiyarto, G. (2005). Competitiveness indicators in the travel and tourism industry. Tourism Economics, 11(1), 25-43.

Guaita, J. M., Martín, J. M., Salinas, J. A., \& Mogorrón-Guerrero, H. (2019). An analysis of the stability of rural tourism as a desired condition for sustainable tourism. Journal of Business Research, 100, 165-174.

Hall, C. M. (2000). Tourism planning: Policies, processes and relationships. Harlow: Prentice Hall.

Hassan, S. (2000). Determinants of market competitiveness in an environmentally sustainable tourism industry. Journal of Travel Research, 38(3), 239-245.

Heath, E. (2003). Towards a model to enhance destination competitiveness: A southern african perspective. Journal of Hospitality and Tourism Research, 10(2), 124-141.

Hong, W. C. (2009). Global competitiveness measurement for the tourism sector. Current Issues in Tourism, 12(2), 105-132.

Huang, J. H., \& Peng, K. H. (2012). Fuzzy Rasch model in TOPSIS: A new approach for generating fuzzy numbers to assess the competitiveness of the tourism industries in Asian countries. Tourism Management, 33(2), 456-465.

Ivanovic, B. (1974). Comment établir une liste des indicateurs de dévelopement. Revue de Statistique Appliquée, 22(2) (París).

Kozak, M., \& Rimmington, M. (1998). Benchmarking: Destination attractiveness and small hospitality business performance. International Journal of Contemporary Hospitality Management, 10, 74-78.

Kozak, M., \& Rimmington, M. (1999). Measuring tourist destination competitiveness: Conceptual considerations and empirical findings. International Journal of Hospitality Management, 18(3), 273-283.

Lozano-Oyola, M., Blancas, F. J., González, M., \& Caballero, R. (2012). Sustainable tourism indicators as planning tools in cultural destinations. Ecological Indicators, 18, 659-675.

Martín, J. M., Rodríguez, J. A., Zermeño, K. A., \& Salinas, J. A. (2018). Effects of vacation rental websites on the concentration of tourists-Potential environmental impacts. An application to the Balearic Islands in Spain. International Journal of Environmental Research and Public Health, 15(2), 347. https://doi.org/10.3390/ijerph15020347.

Martín, J. M., Salinas, J. A., \& Rodríguez, J. A. (2019). Comprehensive evaluation of the tourism seasonality using a synthetic DP2 indicator. Tourism Geographies, 21(2), 284-305.

Martín, J. M., Salinas, J. A., Rodríguez, J. A., \& Jiménez, J. D. (2017). Assessment of the tourism's potential as a sustainable development instrument in terms of annual stability: Application to Spanish rural destinations in process of consolidation. Sustainability, 9, 1692. https://doi.org/10.3390/su9101692.

Mazanec, J. A., \& Ring, A. (2011). Tourism destination competitiveness: Second thoughts on the world economic forum reports. Tourism Economics, 17(4), 725-751.

Mazanec, J. A., Wöber, K., \& Zins, A. H. (2007). Tourism destination competitiveness: From definition to explanation? Journal of Travel Research, 46, 86-95.

Mendola, D., \& Volo, S. (2017). Building composite indicators in tourism studies: Measurements and applications in tourism destination competitiveness. Tourism Management, 59, 541-553.

Merino, M. C., Somarriba, N., \& Negro, A. (2012). Un análisis dinámico de la calidad del trabajo en España. Los efectos de la crisis económica. Estudios de Economía Aplicada, 30(1), 261-282.

Mihalic, T. (2000). Environmental management of a tourist destination: A factor of tourism competitiveness. Tourism Management, 21(1), 65-78.

Mihalic, T. (2016). Sustainable-responsible tourism discourse. Towards 'responsustable' tourism. Journal of Cleaner Production, 111(Part B), 461-470.

Montero, J.-M., Chasco, C., \& Larraz, B. (2010). Building an environmental quality index for a big city: A spatial interpolation approach combined with a distance indicator. Journal of Geographical Systems, 12(4), 435-459.

Navickas, V., \& Malakauskaite, A. (2009). The possibilities for the identification and evaluation of tourism sector competitiveness factors. Engineering Economics, 1(61), $37-44$.

OECD (2010a). A framework for the evaluation of tourism policies and programmes: Final report.

OECD (2010b). Measuring innovation: A new perspective.

OECD (2011). Towards green growth: monitoring progress. OECD Indicators. OECD

Publishinghttps://doi.org/10.1787/9789264111356-en.

OECD (2011b). How's life?: Measuring well-being.

OECD, World Bank Group (2001) (2001). PPPs and the price competitiveness of international tourism destination. Recent advances in methods and applicationsWashington, D.C.: Joint Seminar on Purchasing Power Parities 30 January - 2 February.

OECD, World Bank Group (2001) (2005). Application of the analytic hierarchy process to tourism choice and decision making: A review and illustration applied to destination competitiveness. Tourism Analysis, 10(1), 17-25.

Omerzel, D. G. (2006). Competitiveness of Slovenia as a tourist destination. Managing Global Transitions, 4(2), 167-189.

Pena, J. B. (1977). Problemas de la medición del bienestar y conceptos afines (una aplicación del caso español). Madrid: INE.

Pena, J. B. (2009). La medición del bienestar social: Una revisión crítica. Estudios de Economía Aplicada, 27(2), 299-324 (Valladolid).

Pérez, V., Blancas, F. J., González, M., Guerrero, F. M., Lozano, M., Pérez, F., \& Caballero, R. (2009). Evaluación de la sostenibilidad del turismo rural mediante indicadores sintéticos. Investigación operacional. Vol. 30. Investigación operacional (pp. 40-51). Habana: Universidad de La 1.

Porter, M. E. (1990). The competitive advantage of nations. New York: The Free Press.

Qiu, H., Fan, D. X. F., Lyu, J., Lin, P. M. C., \& Jenkins, C. L. (2018). Analyzing the economic sustainability of tourism development: Evidence from Hong Kong. Journal of Hospitality and Tourism Research, 43(2), 226-248. https://doi.org/10.1177/ 1096348018777046.

Ramos, G., Negro, A., Merino, M. C., \& Somarriba, N. (2010). El empleo en la Unión Europea: Un análisis de la calidad del trabajo. Lan harremanak/22 (pp. 17-43). Universidad del País Vasco, Secretariado de Publicaciones.

Ray, S. (2014). An index of maternal child healthcare status in India: Measuring inter and intra-state variations form capability perspective. Social Indicators Research, 117, 195-207.

Ritchie, J. R. B., \& Crouch, G. (1993). Competitiveness in international tourism: A framework for understanding and analysis. Proceedings of the 43rd congress of association internationale d'experts scientifique de tourisme (pp. 17-23). San Carlos de Bariloche, Argentina, October.

Ritchie, J. R. B., Crouch, G., \& Hudson, S. (2001). Developing operational measures for the components of a destination competitiveness/sustainability model: Consumer versus managerial perspectives. Consumer psychology of tourismHospitality and Leisure edited by J. A.

Rodríguez, J. A. (2012). An index of child health in the least developed countries (LDCs) of Africa. Social Indicators Research, 105, 309-322.

Rodríguez, J. A., Holgado, M., \& Salinas, J. A. (2012). An index of social and economic development in the community's Objective- 1 regions of countries in Southern Europe. European Planning Studies, 20(6), 1059-1074.

Rodríguez, J. A., Holgado, M., \& Salinas, J. A. (2013). An index of progress: Towards the MDG 1 in Southern Africa and the horn of Africa. Applied Research in Quality of Life, 8, $467-480$.

Rodríguez, J. A., Holgado, M., \& Salinas, J. A. (2014). An index of economic and social development in a group of countries in Africa. Applied Research in Quality of Life, 10, 495-508.

Rodríguez, J. A., Holgado, M., \& Salinas, J. A. (2015). An assessment of millennium development goal (MDG) 3 in least developed countries of Asia. Applied Research in Quality of Life, 10, 49-62.

Rodríguez, J. A., Jiménez, J. D., Martín, J. M., \& Salinas, J. A. (2018). Crisis in the horn of Africa: Measurement of Progress towards millennium development goals. Social Indicators Research, 135, 499-514.

Rodríguez, J. A., Jiménez, J. D., Salinas, J. A., \& Martín, J. M. (2016). Millennium development goals 4 and 5: Progress in the least developed countries of Asia. Social Indicators Research, 129, 489-504.

Rodríguez, J. A., \& Salinas, J. A. (2012). An index of maternal and child health in the least developed countries of Asia. Gaceta Sanitaria, 26(2), 190-192.

Saltelli, A. (2007). Composite indicators between analysis and advocacy. Social Indicators Research, 81(1), 65-77.

Somarriba, N. (2008). Aproximación a la medición de la calidad de Vida social e individual en la Europa Comunitaria (Tesis doctoral). Universidad de Valladolid.

Somarriba, N., \& Pena, B. (2009). Synthetic indicators of quality of life in Europe. Social Indicators Research, 96, 115-133.

Somarriba, N., \& Zarzosa, P. (2016). Quality of life in Latin America: A proposal for a synthetic indicator. In indicators of quality of life in Latin America. Social Indicators Research Series, 62. https://doi.org/10.1007/978-3-319-28842-0_2.

Somarriba, N., \& Zarzosa, P. (2018). Quality of life in the European Union: An econometric analysis from a gender perspective. Social Indicators Research. https://doi.org/ 10.1007/s11205-018-1913-4.

Somarriba, N., Zarzosa, P., \& Pena, B. (2015a). The economic crisis and its effects on the quality of life in the European Union. Social Indicators Research, 120, 323-343.

Somarriba, N., Zarzosa, P., \& Pena, B. (2015b). The travel \& tourism competitiveness report 2015: Growth through shocks. (Geneva).

United Nations (1987). Informe de la comisión mundial sobre el medio ambiente y el desarrollo. New York, USA: United Nations.

Wall, G., \& Mathieson, A. (2006). Tourism: Change, impacts and opportunities. England: Pearson. Education Limited.

WCED (1987). Our common future. (report of the world commission on environment and 
development). Oxford and New York: Oxford University Press.

WEF (2007). The travel \& tourism competitiveness report 2007: Furthering the process of economic development. (Geneva).

WEF (2008). The travel \& tourism competitiveness report 2008: Balancing economic development and environmental sustainability. (Geneva).

WEF (2009). The travel \& tourism competitiveness report 2009: Managing in a time of turbulence. (Geneva).

WEF (2011). The travel \& tourism competitiveness report 2011: Beyond the downturn. (Geneva).

WEF (2013). The travel \& tourism competitiveness report 2013: Reducing barriers to economic growth and job creation. (Geneva).

WEF (2015). The travel \& tourism competitiveness report 2015: Growth through shocks. (Geneva).

WEF (2017). The travel \& tourism competitiveness report 2017: Paving the way for a more sustainable and inclusive future. (Geneva).

WTO (1993). Tourism report year 2000 and beyond qualitative aspects. World Tourism Organization: Madrid, Spain.

Zarzosa, P. (1994). El criterio de discriminación en la selección de indicadores de bien estar: Análisis del coeficiente de discriminación de Ivanovic. Estudios de Economía Aplicada, 2, 169-185.

Zarzosa, P. (1996). Aproximación a la medición del Bienestar Social. Valladolid: Secretariado de Publicaciones.

Zarzosa, P. (2005). dirLa calidad de vida en los municipios de la provincia de valladolid. Valladolid: Diputación Provincial.

Zarzosa, P. (2012). The social welfare in Spain before the crisis: Territorial and chronological analysis. International Journal of Advances in Management and Economics, 1(4), 165-171.

Zarzosa, P., \& Somarriba, N. (2013). An assessment of social welfare in Spain: Territorial analysis using a synthetic welfare indicator. Social Indicators Research, 111, 1-23.

Zhang, H., Gu, C.-1., Gu, L.-W., \& Zhang, Y. (2011). The evaluation of tourism destination competitiveness by topsis \& information entropy: A case in the Yangtze River Delta of China. Tourism Management, 32, 443-451.

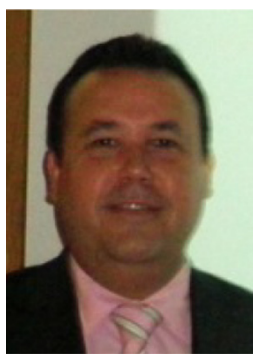

José Antonio Salinas Fernández is associate professor at the Department of Spanish and International Economics, University of Granada, Spain. His research interests include statistical indicators for economic and social development, well-being and tourism competitiveness. He has a large experience as economic consultant for private and public sectors, and his research studies have been published in high impact journals.

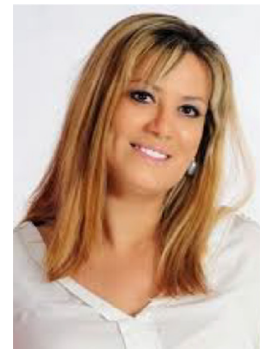

Paula Serdeira Azevedo is assistant professor at the Department of Information Systems and Technology, University of the Algarve, since 1997. The interests of her research focus on the use of Enterprise Resource Planning (ERP) systems to improve competitiveness in the hospitality industry, and in the application of ICT in the tourism sector. She has published her works in international scientific journals and participated on several scientific committees of international conferences.

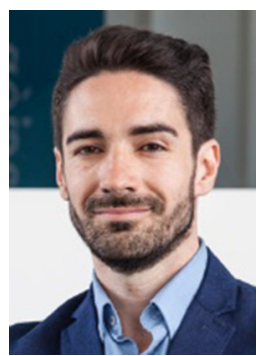

José María Martín Martín is a senior lecturer at the International University of La Rioja and also a lecturer within the School of Economics and Business at the University of Granada, both in Spain. The interests of his research focus on rural tourism, economic sustainability, seasonality and sustainable development. His last projects focus on the evaluation of the socioeconomic impact of the tourist events and the design of anti-seasonality policies.

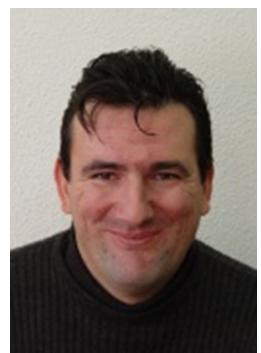

José Antonio Rodríguez Martín is a professor at the Department of Applied Economics within the School of Economics and Business at University of Granada, Spain. The interests of his research focus on human development, sustainable development and social indicators. His studies about economic indicators have been published in several high impact journals, being an expert in the construction of synthetic index. 